\title{
The study of the technological and microbiological parameters of a dietary supplement "Osteovert"
}

The main tasks of the treatment of rheumatologic diseases include minimizing pain and inflammation in the joints, as well as restoring their functions. Duration of the treatment and the chronic course of the disease make it difficult to carry out the anti-inflammatory and analgesic therapy, which is characterized by the negative impact of non-steroidal anti-inflammatory drugs (NSAIDs) on an articular cartilage, as well as on organs of the gastrointestinal tract. In this regard, it is important to create new effective and safe products of plant origin, which use involves fewer side effects and the possibility of a longer period of use.

Aim. To study the technological and microbiological parameters of the combined drug - a dietary supplement "Osteovert" in soft gelatin capsules for use in rheumatology and a dry extract of harpagophytum (Harpagophytum procumbens) used in its production.

Materials and methods. The choice of active components in the composition of a dietary supplement "Osteovert" in soft gelatin capsules was substantiated by the analytical review of drugs used in diseases of the musculoskeletal system and presented at the pharmaceutical market of Ukraine, as well as by the results of the own pharmacological studies.

Results and discussion. The research on studying the technological parameters of soft capsules "Osteovert" promoting improvement of the condition of the musculoskeletal system has been conducted. The active ingredients of capsules are glucosamine sulfate, chondroitin sulfate and a dry extract of harpagophytum roots. According to the methods of the State Pharmacopeia of Ukraine (SPhU) the following pharmacotechnological tests of a dry extract have been conducted: the fractional composition, fluidity, which is characterized by determining the angle of repose and the emptying time, the bulk volume and settled volume, settling qualities and density (bulk density and tapped density). In order to develop the specifications of Ukraine for capsules the organoleptic indicators, uniformity of mass for a unit of a dosed drug and disintegration have been determined. The microbiological indicators of intermediate products and capsules "Osteovert" meeting the requirements of the current regulatory documentation have been determined. The material balance of the batch of capsules "Osteovert" has been calculated.

Conclusions. The pharmacotechnological parameters of a dry extract of harpagophytum have been studied according to the methods of the SPhU. The results of the study were used when substantiating the choice of a dosage form for a dietary supplement "Osteovert". The manufacturing technology and the flowchart for the manufacturing process of capsules "Osteovert" intended for use in diets as an additional source of glucosamine, chondroitin and harpagoside have been developed. The microbiological quality parameters have been determined for the capsules and the dry extract of harpagophytum obtained. The manufacturing technology for capsules "Osteovert" has been implemented in production at the PJSC "DNCLZ Pilot plant".

Key words: soft dosage forms; pharmacotechnological parameters; production; extract of harpagophytum; rheumatologic diseases

\section{А. І. Крюкова, І. М. Владимирова \\ Дослідження технологічних та мікробіологічних показників добавки дієтичної «Остеоверт»}

До основних завдань терапії ревматологічних захворювань відносяться мінімізація болю та запалення в суглобах, а також відновлення їх функцій. Тривалість лікування та хронічний перебіг захворювань ускладнюють проведення протизапальної та аналгетичної терапії, яка характеризується негативним впливом нестероїдних протизапальних засобів (НПЗ3) на суглобовий хрящ, а також на органи шлунково-кишкового тракту. У зв'язку з цим актуальним $є$ створення нових ефективних та безпечних засобів рослинного походження, застосування яких передбачає меншу кількість побічних ефектів та можливість більш тривалого терміну застосування.

Метою роботи було дослідження технологічних та мікробіологічних показників комбінованого засобу - добавки дієтичної у вигляді м'яких желатинових капсул «Остеоверт» для застосування в ревматології та сухого екстракту гарпагофітуму, який використовується при ії̈ виробництві.

Матеріали та методи. Вибір активних компонентів до складу добавки дієтичної у формі м'яких желатинових капсул «Остеоверт» обґрунтовувався аналітичним оглядом засобів, представлених на фрармацевтичному ринку України, що застосовуються при захворюваннях опорно-рухового апарату, та результатами власних фрармакологічних досліджень. 
Результати та їх обговорення. Проведені дослідження з вивчення технологічних параметрів м'яких капсул «Остеоверт», які сприяють покращенню стану опорно-рухової системи. Діючими речовинами капсул є: глюкозаміну сульфат, хондроїтину сульфат та сухий екстракт коренів гарпагофітуму лежачого. За методиками ДФУ проведені фрармакотехнологічні випробування сухого екстракту: фрракційний склад, плинність, що характеризується визначенням кута природного укосу та часом висипання, насипний об'єм та об'єм після усадки, здатність до усадки та густина (насипна густина та густина після усадки). 3 метою розробки технічних умов України для капсул визначені органолептичні показники, однорідність маси для одиниці дозованого лікарського засобу, розпадання. Визначені показники мікробіологічної чистоти для напівпродуктів та капсул «Остеоверт», що відповідали вимогам діючої нормативної документації. Розрахований матеріальний баланс серії капсул «Остеоверт».

Висновки. Досліджені фрармакотехнологічні показники сухого екстракту гарпагофітуму за методиками ДФУ, результати яких використані при обґрунтуванні вибору лікарської фрорми добавки дієтичної «Остеоверт». Розроблена промислова технологія та схема технологічного процесу капсул «Остеоверт», які призначені для використання в раціонах харчування як додаткове джерело глюкозаміну, хондроїтину та гарпагозиду. Для отриманих капсул та сухого екстракту гарпагофітуму визначені мікробіологічні показники якості. Технологія виробництва капсул «Остеоверт» впроваджена в умовах ТОВ «ДЗ «ДНЦЛЗ».

Ключові слова: м'які лікарські форми; фрармакотехнологічні показники; виробництво; екстракт гарпагофрітуму; ревматологічні захворювання

\section{А. И. Крюкова, И. Н. Владимирова}

\section{Исследование технологических и микробиологических показателей добавки диетической «Остеоверт»}

К основным задачам терапии ревматологических заболеваний относятся минимизация боли и воспаления в суставах, а также восстановление их функций. Продолжительность лечения и хроническое течение заболеваний затрудняют проведение противовоспалительной и анальгетической терапии, которая характеризуется отрицательным влиянием нестероидных противовоспалительных средств (НПВС) на суставной хрящ, а также на органы желудочно-кишечного тракта. В связи с этим актуальным является создание новых эффрективных и безопасных средств растительного происхождения, применение которых предусматривает меньшее количество побочных эффектов и возможность более длительного срока применения.

Целью работы было исследование технологических и микробиологических показателей комбинированного средства - добавки диетической в виде мягких желатиновых капсул «Остеоверт» для применения в ревматологии и сухого экстракта гарпагофитума, который использован при ее производстве.

Материалы и методы. Выбор активных компонентов в составе добавки диетической в фрорме мягких желатиновых капсул «Остеоверт» обоснован аналитическим обзором средств, представленных на фрармацевтическом рынке Украины, применяемых при заболеваниях опорно-двигательного аппарата, и результатами собственных фрармакологических исследований.

Результаты и их обсуждение. Проведены исследования по изучению технологических параметров мягких капсул «Остеоверт», которые способствуют улучшению состояния опорно-двигательной системы. Действующими веществами капсул являются: глюкозамина сульфат, хондроитина сульфат и сухой экстракт корней гарпагофритума лежащего. По методикам ГФУ проведены фрармакотехнологические испытания сухого экстракта: фрракционный состав, текучесть, которая характеризуется определением угла естественного откоса и временем высыпания, насыпной объем и объем после усадки, способность к усадке и плотность (насыпная плотность и плотность после усадки). С целью разработки технических условий Украины для капсул определены органолептические показатели, однородность массы для единицы дозированного лекарственного средства и распадаемость. Определены показатели микробиологической чистоты для полупродуктов и капсул «Остеоверт», отвечающих требованиям действующей нормативной документации. Рассчитан материальный баланс серии капсул «Остеоверт».

Выводы. Исследованы фрармакотехнологические показатели сухого экстракта гарпагофитума по методикам ГФУ, результаты которых использованы при обосновании выбора лекарственной формы добавки диетической «Остеоверт». Разработана промышленная технология и схема технологического процесса капсул «Остеоверт», которые предназначены для использования в рационах питания как дополнительный источник глюкозамина, хондроитина и гарпагозида. Для полученных капсул и сухого экстракта гарпагофитума определены микробиологические показатели качества. Технология производства капсул «Остеоверт» внедрена в условиях ООО «ОЗ «ГНЦЛС».

Ключевые слова: мягкие лекарственные фрормы; фрармакотехнологические показатели; производство; экстракт гарпагофитума; ревматологические заболевания

Rheumatologic diseases occupy a significant place in the structure of morbidity of the population of the world. The musculoskeletal system disabilities form the basis of these disorders, and it causes local pain syndromes, which require prolonged drug therapy. The main tasks of the treatment of rheumatologic diseases include minimizing pain and inflammation in the joints, as well as restoring their functions. Mainly advanced age, comorbid diseases, duration of the treatment and the chronic course of the disease make it difficult to carry out the anti-inflammatory and analgesic therapy, which is characterized by the negative impact of non-steroidal 
anti-inflammatory drugs (NSAIDs) on an articular cartilage, as well as on organs of the gastrointestinal tract. Pharmacotherapy of rheumatic diseases should be aimed at prevention of disease progression, as well as prevention of significant structural changes in the tissues of the joint $[1,2]$. Dietary supplements are rather effective preventative agents.

In this regard, it is important to create new effective and safe products of plant origin, which use involves fewer side effects and the possibility of a longer period of use.

Taking this into account the aim of our work was to develop the combined drug - a dietary supplement "Osteovert" in soft gelatin capsules intended for use in diets as an additional source of glucosamine, chondroitin and harpagoside, determine the pharmacotechnological and microbiological parameters of intermediate products and the final dosage form, as well as develop the manufacturing technology for capsules "Osteovert".

The growing interest in soft gelatin capsules is explained by a number of peculiarities and benefits. Firstly, the gelatin shell protects active pharmaceutical ingredients from the action of undesirable factors, and secondly, it stabilizes components that are sensitive to oxidation. In addition, this dosage form can be the basis for reduction of the therapeutic dose, and potential side effects, as well as decrease in financial costs in the process of manufacturing [3].

\section{Materials and methods}

The choice of active components in the composition of a dietary supplement "Osteovert" in soft gelatin capsules was substantiated by the analytical review of drugs used in diseases of the musculoskeletal system and presented at the pharmaceutical market of Ukraine, as well as by the results of the own pharmacological studies.

Standardization of the dry extract of harpagophytum (Harpagophytum procumbens DC) used in production of capsules was conducted by such indicators of quality as "Description", "Loss on Drying", "Heavy metals", "Microbiological purity" in accordance with the requirements of the State Pharmacopeia of Ukraine (SPhU) 2.0 [4].

The indicators of microbiological purity for substances used in the manufacture of dietary supplements are regulated by the requirements of the GN 4.4.8.073-2001 "Temporary hygienic regulations for the content of contaminants of chemical and biological nature in biologically active supplements" [5].

In accordance with the requirements of the $\mathrm{SPhU}$ with the aim of developing the specifications of Ukraine for a dietary supplement "Osteovert" such parameters of quality of the finished dosage form as the organoleptic indicators, uniformity of mass for a unit of a dosed drug and disintegration were determined [4]. When conducting the test on disintegration, water was used as a liquid medium. The device was switched on for $30 \mathrm{~min}$ at a temperature of $36.4^{\circ} \mathrm{C}$, and the condition of capsules was studied.

The material balance of production was calculated as the ratio between the amount of the starting raw material, materials, semi-products and intermediate products used in production, and the amount of the finished product actually obtained, byproducts, waste and losses, i.e. as the ratio between theoretically possible and practically obtained yield of the finished product.

The study in obtaining of the substances, a finished dosage form, and determination of their technological parameters were performed at the premises of the PJSC "DNCLZ Pilot plant".

\section{Results and discussion}

To substantiate the composition of soft gelatinous capsules the characteristic of the starting raw material that determines the functional orientation of the drug being developed is given.

Harpagophytum (Harpagophytum procombens DC) is a promising medicinal plant raw material (MPRM) due to the presence of the anti-inflammatory and analgesic activity. As MPRM the roots of the plant are used, their main active substances are iridoids. The results of clinical studies indicate that harpagoside and harpagide (the major iridoids) are highly selective COX-2 inhibitors with efficiency comparable to classical NSAIDs, and confirm the efficacy of harpagoside in the treatment of the joint pain, back pain and fibromyalgia $[6,7]$.

Chondroprotectors are a group of medicines with the delayed action; their effectiveness is aimed at preserving and improving the condition of joints and the cartilaginous tissue. Chondroitin sulfate optimizes the composition of the synovial fluid, while glucosamine sulfate stimulates formation of the cartilage matrix. The introduction of combination of glucosamine sulfate and chondroitin sulfate is characterized by the synergistic and additive effect, it increases the efficiency of the drug compared to the use of each active ingredient separately $[8,9,10]$.

The composition of a dietary supplement "Osteovert" (the content of 1 capsule) is: Active ingredients: glucosamine sulfate $-300.0 \mathrm{mg}$; chondroitin sulfate $-250.0 \mathrm{mg}$; a dry extract of harpagophytum $-200.0 \mathrm{mg}$. Excipients: soybean oil, lecithin, beeswax, gelatin, glycerin, purified water, iron oxide.

The dry extract of harpagophytum roots was obtained by the general scheme. The raw material crushed to the particle size passing through a sieve with the mesh size of 3-5 $\mathrm{mm}$ in diameter was placed in the extractor with a magnetic stirrer. The extraction was performed in the ratio of the raw material-extractant of $1: 10$ taking into consideration the absorption coefficient of the extractant to the complete extraction of biologically active substances from the raw material. As an extractant ethanol $(20 \%, v / v) \mathrm{R}$ was used. The extract obtained was filtered and concentrated using a rotary evaporator at a temperature of $50-60{ }^{\circ} \mathrm{C}$ to a thick consistency (humidity does not exceed $25 \%$ ). The dense extract obtained was dried to dryness in a vacuum drying cabinet at a temperature of $70-75^{\circ} \mathrm{C}$ and pressure of $80-87 \mathrm{kPa}$.

The dry extract of harpagophytum obtained is a loose, hygroscopic, light brown powder with the odor and taste that are inherent to the raw material of harpagophytum. The loss on drying determined was $3.2 \pm 0.18 \%$. The content of heavy metals in the dry extract was not more than $0.01 \%(100 \mathrm{ppm})$. The results of sieve analysis show that the main fraction of the dry extract was the 
Table 1

Pharmacotechnological parameters of a dry extract of harpagophytum

\begin{tabular}{|c|c|}
\hline $\begin{array}{c}\text { Pharmacotechnological } \\
\text { parameters }\end{array}$ & $\begin{array}{l}\text { The results of } \\
\text { determination }\end{array}$ \\
\hline Bulk volume, $\mathrm{V}_{0}, \mathrm{ml}$ & $123.93 \pm 0.03$ \\
\hline Settled volume, $\mathrm{V}_{10}, \mathrm{ml}$ & $107.90 \pm 0.05$ \\
\hline Settled volume, $\mathrm{V}_{500} \mathrm{ml}$ & $96.94 \pm 0.04$ \\
\hline Settled volume, $\mathrm{V}_{1250}, \mathrm{ml}$ & $94.91 \pm 0.03$ \\
\hline Settling qualities, $\left(\mathrm{V}_{10}-\mathrm{V}_{500}\right)$ & $12.99 \pm 0.06$ \\
\hline Bulk density, $\left(\mathrm{m} / \mathrm{N}_{0}\right), \mathrm{g} / \mathrm{ml}$ & $0.40 \pm 0.03$ \\
\hline Tapped density, $\left(\mathrm{m} / \mathrm{V}_{1250}\right), \mathrm{g} / \mathrm{ml}$ & $0.53 \pm 0.08$ \\
\hline Fluidity, s & $38.51 \pm 0.06$ \\
\hline Angle of repose, ${ }^{\circ}$ & $32.5 \pm 1.43$ \\
\hline
\end{tabular}

powder with the particle size passing through a sieve with the mesh size from $0.2 \mathrm{~mm}$ to $0.31 \mathrm{~mm}$.

According to the methods of the SPhU pharmacotechnological parameters of a dry extract of harpagophytum were determined. The results are presented in Tab. 1.

When studying compressibility the dry extract sticked to hands and to the equipment due to the hygroscopicity of the substance under research. Since a lot of excipients are used when developing solid dosage forms, creation of an oral formulation in the form of soft capsules is rational.

The results of microbiological purity of intermediate products and the final dosage form are presented in Tab. 2.

According to the results of the experimental data obtained the industrial technology for manufacturing the dietary supplement was developed and implemented in production at the PJSC "DNCLZ Pilot plant". The flowchart of the manufacturing process of capsules "Osteovert" developed in the conditions of industrial production is given in Fig.

Stage 1. Preparation of the raw material. The ingredients for the batch are weighed in tared labeled collectors using the balance. The ingredients are sieved with a hand sieve in tared collectors.

The uniformity of sifting is controlled - visible particulate matter in the sifted raw material is absent.
Stage 2. Preparation of the mass for encapsulation. The reactor is charged with the weighted amount of glucosamine sulfate chondroitin sulfate, a dry extract of harpagophytum roots and the part of soybean oil. The content of the reactor is mixed for $15 \pm 1 \mathrm{~min}$. In the reactor with glucosamine sulfate chondroitin sulfate, a dry extract of harpagophytum roots and the part of soybean oil the mass containing soybean oil, lecithin, and beeswax is added. The content of the reactor is mixed at a temperature of $45^{\circ} \mathrm{C}$ for $15 \pm 5 \mathrm{~min}$.

The time of mixing, completeness of dissolution and the mass of the resulting filler are controlled.

Stage 3. Preparation of the gelatinous mass. The reactor is charged with the weighted amount of glycerin and purified water. Stirring the content of the reactor it is heated to a temperature of $60 \pm 2{ }^{\circ} \mathrm{C}$ and continued to mix for another $30 \pm 1 \mathrm{~min}$.

In a $1000 \mathrm{ml}$ graduated beaker the weighted amount of purified water and iron oxide is loaded to prepare the dye solution. The resulting solution is stirred for $15 \pm 1 \mathrm{~min}$.

To the reactor with glycerin and purified water the dye solution is loaded and mixed for $10 \pm 1 \mathrm{~min}$. Then gelatin heated to a temperature of $60 \pm 2{ }^{\circ} \mathrm{C}$ is added. The resulting mass is vacuumed in order to remove air bubbles at the vacuum level of $0.7 \pm 0.1 \mathrm{kgf} / \mathrm{cm} 2$, heated to a temperature of $75 \pm 2{ }^{\circ} \mathrm{C}$ and continued to mix for $90 \pm 20$ min when vacuuming.

The gelatinous mass obtained is filtered through a capron filter into a thermostated container for the gelatinous mass.

The completeness of dissolution of the gelatinous mass and the temperature mode are controlled.

Stage 4. Preparation and filling of gelatinous shells. The gelatinous mass and the filler from thermostated containers are introduced on an automatic line for manufacturing soft gelatin capsules, and encapsulation is carried out.

The quality of capsules is controlled by the following indicators: appearance, the average weight, disintegration and dissolution.

Stage 5. Drying of capsules. Wet capsules are dried in small trays for drying capsules are set on barrows for trays. After drying the quality of dried capsules is controlled for the absence of mechanical damage and the presence of different kind of deformations.

Table 2

The microbiological indicators of intermediate products and capsules "Osteovert"

\begin{tabular}{|l|c|c|c|c|c|}
\hline \multirow{2}{*}{ Indicator } & The requirements & \multicolumn{5}{|c|}{ The results of the control * } \\
\cline { 3 - 6 } & of AND & Sample 1 & Sample 2 & Sample 3 & Sample 4 \\
\hline Total aerobic bacteria count (CFU g/ml) & $10^{4}$ & 280 & 30 & 42 & 390 \\
\hline Total yeasts and molds (CFU g/ml) & $10^{2}$ & $<10$ & $<10$ & $<10$ & $<10$ \\
\hline \multicolumn{5}{|c|}{ The presence of bacteria of the family } \\
\hline Enterobacteriaceae & absence & absent & absent & absent & absent \\
\hline S. aureus & absence & absent & absent & absent & absent \\
\hline P. aeruginosa & absence & absent & absent & absent & absent \\
\hline
\end{tabular}

Notes: * sample 1 - a dry extract of harpagophytum roots; sample 2 - glucosamine sulfate; sample 3 - chondroitin sulfate; sample 4 capsules "Osteovert". 
Raw material, intermediate products and materials
Manufacture of a dietary

supplement "Osteovert"

Glucosamine sulfate, chondroitin sulfate, a dry extract of harpagophytum roots, soybean oil, lecithin, beeswax

\section{Stage 1}

Preparation of the raw material

Stage 2

Preparation of the mass for encapsulation
In-process control
The amount of the raw material, uniformity of the sieved raw material
Gelatin, glycerin, purified water, iron oxide
Stage 3

Preparation of the gelatinous
The time of mixing,

completeness of dissolution,
Completeness of dissolution of the gelatinous mass,

\section{Stage 4}

Preparation and filling of gelatinous shells

Automatic line for manufacturing
Control of the intermediate product (appearance, the average weight, disintegration and dissolution tests)

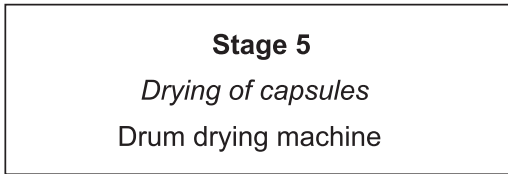

Packing of capsules

\section{Stage 6}

Dispensing of capsules in blister packs

Automatic sorting machine, inspection table
Temperature and duration of drying, the residual moisture content of capsules
Packs, patient information leaflets

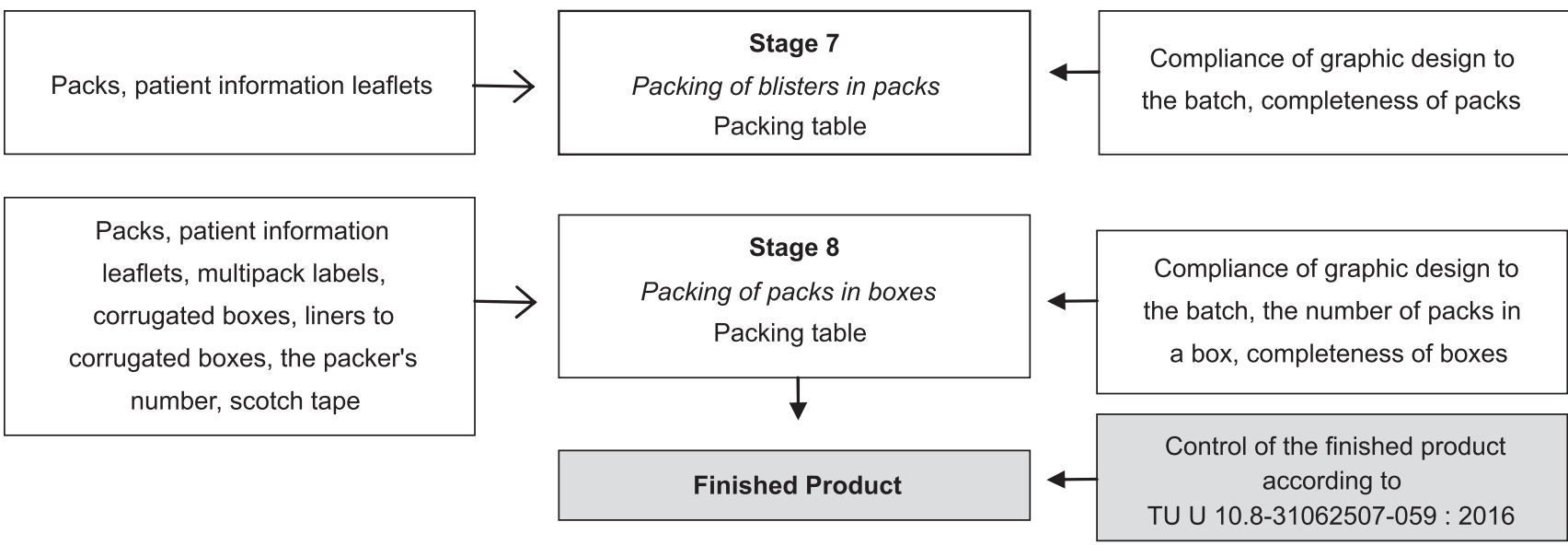

Temperature mode, correctness of printing (batch number, shelf-life), the number of capsules in a blister, accuracy of labeling

Fig. The flowchart of the manufacturing process of a dietary supplement "Osteovert" in soft gelatin capsules 
The material balance of the batch (1 thousand packs) of the dietary supplement "Osteovert"

\begin{tabular}{|c|c|c|c|c|c|}
\hline \multicolumn{3}{|l|}{ Spent } & \multicolumn{3}{|l|}{ Obtained } \\
\hline \multirow{2}{*}{$\begin{array}{l}\text { The name of the raw material, semi- } \\
\text { products and materials }\end{array}$} & \multicolumn{2}{|c|}{ Amount } & \multirow{2}{*}{$\begin{array}{l}\text { The name of the finished } \\
\text { product, waste and losses }\end{array}$} & \multicolumn{2}{|c|}{ Amount } \\
\hline & $\mathrm{kg}$ & ths pcs & & $\mathrm{kg}$ & ths pcs \\
\hline The raw material: & & & $\begin{array}{l}\text { The dietary supplement } \\
\text { “Osteovert", soft gelatin } \\
\text { capsules No. 32, } 40 \text { packs in a } \\
\text { multipack label, including: }\end{array}$ & 71.674 & 1.000 \\
\hline Glucosamine sulfate & 10.08 & & PVC film + aluminium foil & 9.81 & \\
\hline chondroitin sulfate & 8.4 & & Leaflet & & 1.000 \\
\hline A dry extract of harpagophytum roots & 6.72 & & Pack & & 1.000 \\
\hline Soybean oil & 21.168 & & Corrugated box & & 0.025 \\
\hline Lecithin & 2.016 & & A liner to corrugated boxes & & 0.050 \\
\hline Beeswax & 2.016 & & Adhesive tape (scotch tape) & & 0.00047 \\
\hline Gelatin & 11.070 & & Multipack label No.40 & & 0.025 \\
\hline Glycerin & 4.98 & & The packer's number & & 1.025 \\
\hline Iron oxide & 0.110 & & Losses: & & \\
\hline Purified water & 9.987 & & Mechanical dead weight losses & & \\
\hline Materials: & & & Waste: & & \\
\hline PVC film $(150 \times 0.2) \mathrm{mm}$ & 8.288 & & PVC film + aluminium foil & & \\
\hline Aluminium foil $(150 \times 0.02) \mathrm{mm}$ & 1.932 & & Leaflet & 0.41 & \\
\hline Leaflet & & 1.005 & Pack & & 0.005 \\
\hline Pack & & 1.005 & Multipack label No. 40 & & 0.005 \\
\hline Corrugated box & & 0.026 & Corrugated box & & 0.004 \\
\hline A liner to corrugated boxes & & 0.052 & A liner to corrugated boxes & & 0.001 \\
\hline Multipack label No.40 & & 0.029 & The packer's number & & 0.002 \\
\hline Adhesive tape (scotch tape) & & 0.00047 & & & \\
\hline The packer's number & & 1.03 & & & \\
\hline Total: & 86.767 & 3.14747 & Total: & 86.767 & 3.14747 \\
\hline
\end{tabular}

The temperature, duration of drying, and the residual moisture content of capsules are controlled.

Stage 6. Dispensing of capsules in blister packs. The standard capsules are dispensed on a blister packing machine in blisters of polyvinyl chloride film (PVC) and aluminum foil; there are 8 capsules in a blister from PVC film and aluminum foil.

The temperature mode, correctness of printing (batch number, shelf-life), the number of capsules in a blister, accuracy of labeling are controlled.

Stage 7. Packing of blisters in packs. In a carton pack 3 blisters with the patient information leaflet and the packer's number are placed.

The compliance of graphic design to the batch and completeness of packs are controlled.

Stage 8. Packing of packs in boxes. 40 Packs are placed in a corrugated box, on which a multipack label with the packer's number is placed.

The compliance of graphic design to the batch, the number of packs in a box, and completeness of boxes are controlled.

The finished product is controlled according to the requirements of TU U 10.8-31062507-059:2016 "Dietary supplements based on oils and animal fats".
The soft capsules obtained are of a red-brown color, have an elongated shape, their surface is smooth without the presence of air bubbles and particulate matter. When studying capsules by the indicator "Disintegration of tablets and capsules" it was found that the soft capsules disintegrated within 10-14 min.

To substantiate the correctness of the choice and organization of the technological process and develop the manufacturing specification the material balance of production of a dietary supplement "Osteovert" was calculated. It is given in Tab. 3 .

According to the results of the material balance the main technical and economic indicators of production, such as regulated standards of expenses for the raw material, materials, semi-products and energy source per unit of the finished product were calculated.

\section{CONCLUSIONS}

The pharmacotechnological parameters of a dry extract of harpagophytum have been studied according to the methods of the SPhU. The results of the study were used when substantiating the choice of a dosage form for a dietary supplement "Osteovert". The manufacturing technology and the flowchart for the manufacturing process of capsules "Osteovert" intended for use in diets as an addi- 
tional source of glucosamine, chondroitin and harpagoside have been developed. The microbiological quality parameters have been determined for the capsules and the dry extract of harpagophytum obtained. To calculate the main technical and economic indicators of production (regulated standards of expenses for the raw material, materials, semiproducts and energy source) the material balance for the batch of capsules "Osteovert" was calculated. In order to develop the specifications of Ukraine for capsules the organoleptic indicators, uniformity of mass for a unit of a dosed drug and disintegration have been determined. The microbiological indicators of intermediate products and capsules "Osteovert" meeting the requirements of the current regulatory documentation have been determined.

Conflict of Interests: authors have no conflict of interests to declare.

\section{REFERENCES}

1. Sellam, J. In EULAR Compendium on Rheumatic Diseases / J. Sellam, G. Herrero-Beaumont, F. Berenbaum // BMJ. - 2009. - P. $444-463$.

2. Wallace, D. J. New European Recommendations (European League against Rheumatism 2008) for the management of Lupus Erythematosus : American perspective / D. J. Wallace // Pol. Arch. Med. Wewn. - 2008. - Vol. 118, Issue 7-8. - P. 402-403.

3. Гриненко, А. Преимущества капсул из растительного сырья / А. Гриненко // Новости GMP. - 2017. - № 1 (12). - С. $190-192$.

4. Державна фармакопея України : в 3-х т. / Державне підприємство «Український науковий фармакопейний центр якості лікарських засобів». - 2-е вид. - Х. : Український науковий фармакопейний центр якості лікарських засобів, 2015. - Т. 1. - 1128 с.

5. Тимчасові гігієнічні нормативи ГН 4.4.8.073-2001 : постанова Головного державного санітарного лікаря України від 20.04.2001 p. № 131. - К., 2001.

6. Effects of Harpagophytum procumbens (devil's claw) on sensory, motor und vascular muscle reagibility in the treatment of unspecific back pain / H. Göbel, A. Heinze, M. Ingwersen et al. // Schmerz. - 2001. - Vol. 15, Issue 1. - P. 10-18.

7. Effectiveness and safety of Devil's Claw tablets in patients with general rheumatic disorders / M. Warnock, D. McBean, A. Suter et al. // Phytother. Res. - 2007. - Vol. 21, Issue 12. - P. 1228-1233. doi: 10.1002/ptr.2288

8. Кригштейн, О. С. Оценка доказательств эффективности средств, претендующих называться «структурно-модифицирующими препаратами», 2004-2007 гг. / О. С. Кригштейн, Г. Ш. Голубев // Клин. фармакол. и фармакоэкономика. - 2008. - № 1. - С. 55-58.

9. Hochberg, M. Structure effects of chondroitin sulfate in knee osteoarthritis : an updated meta-analysis of randomized placebo-controlled trial of 2-year duration / M. Hochberg // Osteoarthritis Cartilage. - 2010. - Vol. 18. - P. S28-S31. doi: 10.1016/j.joca.2010.02.016

10. Total joint replacement after glucosamine sulphate treatment in rnee ostheoarthritis : results of a mean 8-year observation of patients from two previous 3-year, randomized, placebo-controlled trials / O. Bruyere, K. Pavelka, L. C. Rovati et al. // Osteoarthritis Cartilage. - 2008. - Vol. 16, Issue 2. - P. 254-260. doi: 10.1016/j.joca.2007.06.011

\section{REFERENCES}

1. Sellam, J, Herrero-Beaumont, G, Berenbaum, F. (2009). In EULAR Compendium on Rheumatic Diseases. BMJ, 444-463.

2. Wallace, D. J. (2008). New European Recommendations (European League against Rheumatism 2008) for the management of Lupus Erythematosus: American perspective. Pol. Arch. Med.Wewn., 118 (7-8), 402-403.

3. Grinenko, A. (2017). Novosti GMP, 1 (12), 190-192.

4. Derzhavna Farmakopeia Ukrainy : $v 3$ t. (2015). Kharkiv: Ukrainskyi naukovyi farmakopeinyi tsentr yakosti likarskykh zasobiv, $1,1128$.

5. Postanova Holovnoho derzhavnoho sanitarnoho likaria Ukrainy vid 20.04.2001 r. № 131. (2011). Tymchasovi hihienichni normatyvi HN 4.4.8.073-2001. Kyiv.

6. Göbel, H., Heinze, A., Ingwersen, M. et al. (2001). Effects of Harpagophytum procumbens (devil's claw) on sensory, motor und vascular muscle reagibility in the treatment of unspecific back pain. Schmerz, 15 (1), 10-18.

7. Warnock, M., McBean, D., Suter, A. et al. (2007). Effectiveness and safety of Devil's Claw tablets in patients with general rheumatic disorders. Phytother. Res., 21 (12), 1228-1233. doi: 10.1002/ptr.2288

8. Krigshtein, O. S., Golubev, G. Sh. (2008). Klinicheskaia farmakologiia i farmakoekonomika, 1, 55-58.

9. Hochberg, M. C. (2010). Structure-modifying effects of chondroitin sulfate in knee osteoarthritis: an updated meta-analysis of randomized placebo-controlled trials of 2-year duration. Osteoarthritis and Cartilage, 18, S28-S31. doi: 10.1016/j.joca.2010.02.016

10. Bruyere, O., Pavelka, K., Rovati, L. C., Gatterová, J., Giacovelli, G., Olejarová, M., Reginster, J. Y. (2008). Total joint replacement after glucosamine sulphate treatment in knee osteoarthritis: results of a mean 8-year observation of patients from two previous 3-year, randomised, placebo-controlled trials. Osteoarthritis and Cartilage, 16 (2), 254-260. doi: 10.1016/j.joca.2007.06.011

\section{Information about authors:}

Kriukova A. I., postgraduate student of the Department of Pharmacognosy, National University of Pharmacy. E-mail: kriukova92@gmail.com

Vladymyrova I. M., Doctor of Pharmacy (Dr. habil.), associate professor of the Department of Pharmacognosy, National University of Pharmacy

Відомості про авторів:

Крюкова А. І., аспірант кафедри фармакогнозії, Національний фармацевтичний університет. E-mail: kriukova92@gmail.com

Владимирова I. М., д-р фарм. наук, доцент кафедри фармакогнозії, Національний фармацевтичний університет

Информация об авторах:

Крюкова А. И., аспирант кафедры фармакогнозии, Национальный фармацевтический университет. E-mail: kriukova92@gmail.com

Владимирова И. Н., д-р фарм. наук, доцент кафедры фармакогнозии, Национальный фармацевтический университет 